\title{
The missio Dei as context for a ministry to refugees
}

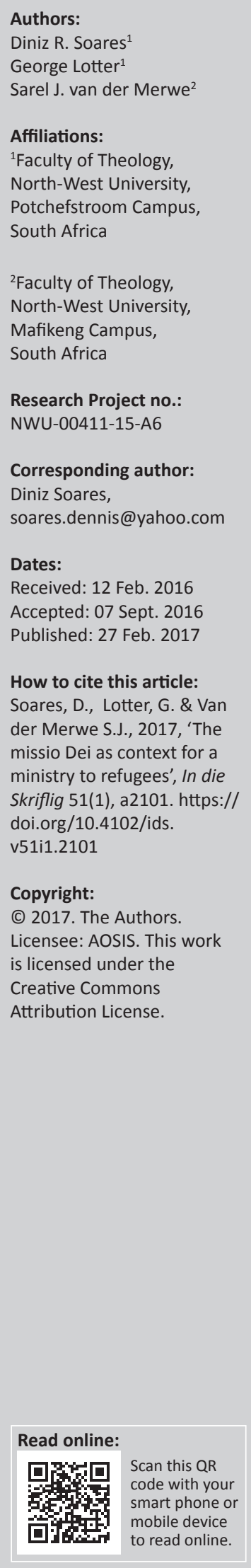

The current global escalation of refugees and involuntary migration, due to the effects of war and world disasters, makes it imperative to devise an effective approach to care for refugees. This article, therefore examines the problem of displacement from the perspective of missio Dei. It presents God's active involvement in his creation, recreating it and providing particular care for the vulnerable and refugees.

\section{Introduction}

The refugee problem and displacement of individuals raises serious concerns such as disruption of people's lives in the sending countries and it places a burden in the receiving countries which at times leads to internal conflicts with the receiving communities. In a refugee report released by the UN agency on refugees (UN 2015), it is mentioned that there are an estimated 65.3 million individuals that are displaced in the world. In a reaction to this alarming situation by the Secretary General of the UN, Bann Ki-Moon (2015) states that the challenge of global displacement is not just a crisis of 'numbers' only but also a 'crisis of solidarity'. He further points out that despite the fact that a greater fraction of the displaced people are hosted in the developing countries, the burden would be eased with the sharing of responsibility among nations.

In Africa alone, thousands of displaced people have left their places of origin to seek refuge in neighbouring states as per statistics to be presented later. This refugee crisis has now affected other parts of the globe that did not register high influx of refugees in the past. Over one million refugees have risked their lives as they cross the Mediterranean Sea by boats to seek refuge in Europe (Weber 2016:28). This article proposes a ministry to refugees from the context of missio Dei. It explores God's concern towards refugees and displaced people. God's mission is disseminated in relation to the sending of the Son, the incarnation of God, the Son and his mission and ministry to the destitute of society. The article further describes the missio Dei in terms of provision for refugees, challenges faced by refugees and the responsibility that the church has towards refugees and the displaced in fulfilling the missio Dei.

\section{The missio Dei: Definition and background}

Missio Dei is the Latin term for 'the sending of God' which dates back to Saint Augustine's Trinitarian theology, in which he described God's work in restoring the world with the participation of the church (Bosch 1991:390). The term is also of great significance to Karl Hartenstein's missiology, who related it to Karl Barth's teaching on the doctrine of the Trinity in a lecture on mission presented in 1928 (Hartenstein 1934:217-229). However, the term is more closely associated with the 1952 International Missionary Council held in Willingen (West Germany) and a preseding conference held in Whitby, Ontario in 1947, on changing trends in mission in the church and society prior to World War II (Bosch 1991:390; Engelsviken 2003:482). In Willingen, the missio Dei came to be understood as the work of the triune God - God the Father, God the Son and God the Holy Spirit. Mission was viewed in terms of Barth's missiological theology as God at work, in which the church takes a participatory role.

Mission belongs to God and the church is given the privilege to participate in the process of recreation (Hoffmeyer 2001:108; Wolters 2001:12-13). The God of creation in Genesis continues to perform acts of creating and recreating, in contrast to deism that denies God's continuous interaction with the affairs of his creation (Dulles 2005:28; Wainwright 1991:124-125). This is never clearer than in Jesus Christ's own words: 'My Father is always at his work to this very day, and I too am working' (Jn 5:17). While mission is what God does, missions consist of the activity that the church does in the community where it is found in obedience to God the founder of mission (Bosch 1991:390; Dulles 2005:28-391). 


\section{God the initiator of missio Dei to the displaced}

The incarnate Jesus was the presence of God in his fullness to fulfil his mission to restore man. Starting with the fall of man in Genesis 3, man's state of deprivation puts him in a disadvantaged position. His alienation due to sin creates a sociological problem of displacement and marginalisation. It breaks the relationship between man and God as well as man and fellow man. This relational imbalance is seen in the Garden of Eden when Adam breaks God's law and he is consequently expelled from the Garden. According to Gaebelein (1990:59) the reality of death was initiated in Adam and Eve's being 'cast out of the garden'. A term used in the Mosaic Law meaning to 'be put to death' and 'to be cut off from his people' (Ex 31:14). In this instance in the garden, it meant to be cut off from the protective presence of the Eden community (cf. Genesis 4:14; Gaebelein 1990:59).

The event in Eden represents from both the sociological and spiritual perspective, a picture of displacement and marginalisation that derives from disobedience to the Creator's laws (Gn 3:15). However, God continues to show his grace and mercy to Adam in his exile life. He provides clothes for Adam and Eve (Gn 3:31). God's care and provision to man anticipates the remote restoration of man's blessing through the Sinai Covenant and the Torah (Gaebelein 1990:60). The point to emphasise in this passage is that of a God who cares for those who are helpless. Munroe (2004:125) explains that man lost his relationship with God due to the fall and God is in the process of restoring this fellowship with man now, and not only in the remote future through the incarnate Jesus Christ.

\section{Jesus Christ's mission to people on the margin}

It can be argued from this perspective that the introduction of sin badly affects man's relationship which in turn leads to relational imbalances such as greed and wars by which the vulnerable people in the world suffer the most. It is this stance that refugees and their situation of displacement place them in a disadvantaged position. This leads to the complex ramifications of sin reflected in various social injustices caused by fellow man. Refugees can thus be safely included in the scope of Jesus' mission who came to rescue such a population group as part of his overall mission in obedience to the Father's sending. Jesus announces his mission in Luke 4:18-19 as fulfilment of the prophetic text in Isaiah 61:1-2. According to this passage, the mission of Jesus Christ encompasses both the physically fortunate and the destitute of this world. It also represents the physically fortunate who are spiritually deprived. Yet I agree with Gaebelein (1990:867, 891) that often the underprivileged state creates a greater urge to seek God as compared to materially blessed individuals. Jesus Christ is commissioned by the Spirit of God to fight for the spiritual and social cause of the underprivileged such as the poor, the captive, the blind and those that are bruised.
The incarnate Jesus is the perfect expression of God's love to the world. His birth, death and resurrection fulfil in a nutshell the message of the gospel in the Ten Commandments (Ex 1:20-26), which Jesus encapsulated in a single key word, love. As Newlands (2006:84) confirms, Jesus Christ's resurrection is an expression of love and hope that enacts the well-being of all humans who live under oppression. It is in Jesus Christ, where mission seeks to address the pain and the distress caused by man's disobedience to God's commands, that social responsibility is part and parcel of evangelistic endeavour (Bosch 1991:405). God's mission involves restoring man to the life of fellowship with God and to enjoy abundant life, which will reach its full potential in the future Kingdom.

Jesus Christ's mission related to people of various social backgrounds, even those on the margins of society. He interacted with publicans, entered the house of Zacchaeus and ate with sinners, and the rejected of society (Lk 19:1-10). Chester (2011:87-88) explains how interaction with Jesus made Zacchaeus a changed man and freed him of the bondage of greed. His repentance was evidenced by his intention to repay fourfold to those he defrauded. Jesus accepted the marginalised and the lost, seeking to bring them into a relationship with God. Talking from a counselling perspective, Anderson (2010:84) points out that the kingdom of God does not discriminate between believers and nonbelievers; caregivers must similarly accept care for people as individuals created in God's image.

In the Gospel of Luke, Jesus is the God-Man who cares for the downtrodden. He praises a Samaritan, a member of a culturally marginalised group, for rescuing and caring for a man attacked by robbers and left dead by the road side (Lk 10:30-37). Luke depicts Jesus as the Saviour of both the rich and the poor. As Goheen (2005:13) relates, he initiates the reversal of the fate of the dispossessed and the oppressed of the society in his challenge to the rich to share their wealth with the poor. Jesus also healed people as part of the missio Dei. His message and acts of healing were beyond measure, yet they brought opposition from the leaders of his time and took him to the cross, yet never limiting his mission in the world (Bevans 2007:8).

According to Bosch (1991:32-34), Jesus' message regarding the kingdom includes God's power that attacks the evils of society in whatever form they manifest - pain, disease, demon possession, and brokenness in human relations. He expressed the love of God to those on the margins of society and presented them with the possibility of a new life in God's kingdom. The Gospels portray the saving of individuals in a holistic way, where the word to save (Greek: sozein) is more than a religious term; it goes beyond the salvation of soul to include care for the person in his totality.

This missio Dei may not be realised without taking into account the psycho-social context of the marginalised and the poor. The good news to the poor means a continual struggle to eradicate social evils that impede fullness of life found in 
Jesus Christ (Jn 10:10). Bosch (1991:405) explains that the missio Dei implies more than evangelistic work; it calls for believers to become involved in social responsibilities. It is the proactive involvement with the marginalised in the society, such as the poor and the sick, because their plight hinders God's intended purpose of a healthy communion with Him (Bosch 1991:28; Holloway 2009:138). God's care for the marginalised provides a platform to care for the refugees.

\section{Missio Dei: Provision for the care for refugees}

The Bible records incidents of displacement as a result of various factors in the life of Israel. As in the words of Elliott (2011:198), the Bible is an inspiring record of 'dispossessed identity' and people who claim their identity and home in God. He maintains that since the Bible is inspired by refugees and was written by refugees, it would be more rewarding to read it from that perspective.

The problem of human displacement was not foreign to the Jewish nation in the Bible. In earlier years Israel lived as a semi-nomadic tribe and experienced various social challenges typical to the surrounding tribes, while emerging as a nation (McDermott 2003:82-83; Petit 2012:203). The difficulties of mass movement continued even after Israel settled as a nation. The exilic experiences of Israel, both in Syrian captivity in 722 bc possibly by Sargon II (cf. 2 Ki 17:4; Walvoord \& Zuck 1985:571) and Babylon captivity in 586 bc (Ez 17:13) provide examples of forced displacement. Influential families and key leaders were taken to exile for approximately 70 years (Scott 1995:60-61, 108). Abraham took refuge in Egypt forced by a draught situation in the Land of Promise (Gn 12:10-13:2). Joseph and Mary fled to Egypt to save the child Jesus from Herod's cruel campaign to kill male babies in the Holy Land in order to safeguard his throne (Mt 2:13-23).

In all these instances God remained faithful to groups and individuals involved. He also restored them from their vulnerable and humiliating situation. He ensured their protection and kept the hope alive of returning to the Land of Promise through the message of the prophets. The Lord promised to turn their mourning into joy (Jr 31:2, 9, 13; Stulman 2004:20-23).

God shows concern for the well-being of the foreigner, viz. to provide for sabbatical rest (Ex 20:10; 23:12; Dt 5:14), and to ensure justice in courts (Dt 1:16). God's law toward the foreigners ensured that they received the same protection as the people of God and were not to be discriminated against because of their nationality. Israel had the social obligation to treat equally anyone who sought protection on its home soil, regardless of ethnicity (Riggans 1983:120). The Torah prohibited Israel from committing oppressive acts against foreigners. It states that 'Also thou shalt not oppress a stranger: for ye know the heart of a stranger, seeing ye were stranger in the land of Egypt' (Ex 23:9). It is apparent that
Israel's oppression in the land of Egypt was to serve as valuable lesson to develop compassion for those who would come to take refuge in the Holy Land.

Although the Bible does not condone criminality, it makes provision for the protection of people who unintentionally committed a crime to seek asylum in the Holy Land. Hence foreigners also had access to cities of refuge (Nm 35:15; Josh 20:9). Such provision is earlier stated in Numbers 35:6 where God instructed the children of Israel to set aside six cities of refuge that served to protect both nationals and foreigners if their lives were endangered.

Foreigners were to participate in religious festivities (Lv 16:29; Nm 9:14; Dt 16:1, 11). They also had the right to food security which was provided through the procedure for gleaning for sustenance. Farmers were to intentionally leave behind the harvest on the corners of their fields for the vulnerable groups to benefit ( $\mathrm{Lv}$ 23:22). Deuteronomy 24:20 repeats the same guidelines for the harvest of the olive tree and refers to the same disadvantaged groups who were to benefit from the harvest - the stranger, the fatherless and the widow. They also benefited from financial aid through triennial tithe (Dt 26:11ff.; Bromiley 1988:569). Those who had food in abundance were to testify before God under oath that they had fulfilled their obligation towards the underprivileged (Dt 26:14).

A safe inference can be reached from the provisions made in the passages discussed above that God holds in high regard the wellbeing of foreigners. The Lord's concern for the stranger lies at the heart of the laws of God in Scripture. The elect nation of Israel was to protect the lives of the displaced and strangers that came to settle within the borders of the Promised Land. These laws reflected the value that God places on displaced people and also allowed them to enjoy fellowship with God in the temple alongside the elected nation of Israel.

The care for the disadvantaged also bears a divine reward. Jesus promises a reward to whoever would give a cup of water to the defenceless, the 'little ones' (Mt 10:42). While a different view sees this text as referring to the disciples of Jesus who do not hold any position (Mounce 1991:99), the fact remains that it refers to those who are in a disadvantaged position. Hospitality to proclaimers of the good news is equalled to hospitality to Jesus and God himself. This hospitality also needs to be shown to the oppressed and marginalised in society such as the victims of persecution. In Matthew 25:31-40 Jesus Christ further teaches that those who bring relief to the poor for his name's sake shall be rewarded. God expects us to act on his behalf and share what we have with the underprivileged despite our limited resources. Refugees also face many challenges as they flee to other parts of the globe.

\section{The refugees' challenge in the context of South Africa}

The situation of refugees is a social concern that deprives individuals from dignity and the privilege to enjoy God's gift of life to its fullest. Such mass movement due to cruelties of 
war and human rights abuse have exponentially increased at an alarming rate, reaching 51.2 million in 2013. The United Nations High Commissioner for Refugees (UNHCR) points that the refugee population has comparatively exceeded the populations of countries such as South Africa, Spain or South Korea (UN 2009:2; 2013:2).

According to Dalton-Greyling (2008:1) there has been a notable increase in refugees in South Africa from 6619 in 1997 to almost 30000 in 2006. Most recent statistics reveal that South Africa continues to be a major destination for asylum seekers and refugees sharing about 1217708 of the 62.3 million individuals forcibly displaced in the world (UNHCR 2015:59).

Refugees are faced with numerous challenges as they enter hosting countries and communities. South Africa being one of the key hosts of displaced people is not an exception of such refugee challenges. There are many plausible developments towards the protection of refugees, in terms of better laws that protect them, and various strategies at grassroots levels, such as the banning of refugee camps and community integration (Khan 2007:2). However, there is a challenge in implementing these laws. Both refugees and the receiving communities are not well educated regarding refugee policies and documents (2007:6-5). The safety of refugees is still a matter of concern as they are at times vulnerable to police brutality. Some salient cases include that of the Police inciting dogs to savage four illegal immigrants of Mozambican origin (Bruce 2002; Special Assignment Benoni Dog Unit 1, 2014). Although the latter incident has a racist appeal, literature has shown that racism and xenophobic behaviour have a common denominator which is the dislike of aliens' (Auerbach 2001). Other social challenges on displaced groups are the xenophobic attacks on foreigners that brought back painful memories of the 2008 xenophobic incidents which left many refugees and foreigners dislodged and stranded (SAHO 2015). A recent resurgence of xenophobia early in 2015, reflects how this social evil continues to pose threats to foreigners such as the case of taxi driver Emidio Macia being dragged to death (IOL 2013; Sosibo 2013;) and the brutal attack and killing of Emmanuel Sithole on 8 April 2015 (Tromp \& Oatway 2015). More recent sporadic attacks on foreigners that ignited in some areas of KwaZulu Natal spread to other provinces causing serious concerns in the community of foreign nationals (Wicks 2015). There are continuous conflicts involving burning and looting of shops owned by foreigners in towns and villages (Cornish 2015). All this creates a pathological environment that may lead to an unhealthy society that is intolerant of refugees and displaced people.

Other general perceptions about refugees and foreigners are that they are seen as people who bring diseases into the country and steal women from the nationals (Human Rights Watch 1998). There is a generally feeling that foreigners are stealing jobs and that they are the main cause of crimes perpetrated in the communities (SAHO 2015). This sentiment is not confined to South Africa; many nationals in the
Southern African Development Community (SADC) countries have shown the same concern over foreigners, although there is no official data to prove such concerns. In a survey made in SADC countries, the majority of subjects interviewed accused foreigners of taking employment away from citizens. Crush and Pendleton (2004) point out the following:

Perhaps the most significant and consistent finding is the fear certainly not confined to Southern Africa - that migrants steal rather than create jobs. Although the majority of people in all countries see immigrants as a threat to jobs, very few have personal knowledge or experience of such an occurrence. (p. 2)

One particular study has revealed that worsening economic conditions in South Africa and joblessness could be the main factor triggering xenophobic attacks. Nationals continue to blame foreigners for joblessness and other social evils as a scapegoat to a complex social problem. Most often such perception of foreigners turns to be contradictory to scientific research showing that foreigners contribute to job creation even in the South African situation (Wilkinson 2015). Nationals also feel that foreigners should remain in their countries of origin and resolve their problems rather than coming and competing for scarce resources in the receiving country (Nyamnjoh 2006:45; Umezurike \& Isike 2013:55).

There is also the concern of corrupt officials who take advantage of vulnerable refugees by demanding or accepting bribes from refugees and illegal immigrants in exchange for their release or prevention of deportation (Landau 2005:11). This also happens with some refugees with legal asylum documents. In some instances the issuing of such documents may be purposely slowed down to facilitate corruption (Palmary 2002:9). After establishing some of the major challenges faced by refugees, the following segment will discuss the role of the church towards providing care in response to the missio Dei.

\section{The church's responsibility for the displaced}

The church has to be engaged in God's fight over the reign of evil (Bosch 1991:391). The church exists for the sake of obedience to God's mission and not the other way round (Galgalo 2012:37). Wright (2006:62) states that in missio Dei the emphasis is not so much on the fact that God tasks the church for mission, but that He owns the church for his mission to reach the world. Bosch (1991) elaborates as follows:

The classical doctrine on the missio Dei as God the Father sending the Son, and God the Father and the Son sending the Spirit was expanded to include yet another 'movement': Father, Son and Holy Spirit sending the church in the world. (p. 390)

Arguing from the context of liberal democracy in South Africa, Vorster (2007:256) points out that the church is a community of people called out for a purpose to provide service in the kingdom of God, in obedience to God, acting according to the principles found in the Ten Commandments. The church's spiritualism should not be equated to a holiness, 
which separates it from the world as spiritual and sacred, but in renewing the society in the light of kingdom principles (2007:257). He adds that such separation creates a vacuum in the society that is eventually filled by 'secular ideas'. The church has to be an example of love, stewardship, self-denial and obedience to God (2007:258-259). She should be engaged in preaching Christ as hope to the troubled community. The church has to restore its holiness by becoming a strong voice in opposing mistakes of the past neglect to the poor, the downtrodden and the sick (2007:256-258).

The church's message and action should avoid confining salvation to a certain few, but rather emulating Christ's approach to salvation that encompasses all of creation. The missio Dei would, as such, stretch across all the ecological, political and social concerns of humanity, since God is at work in all areas of his creation (Gallagher 2006:26).

After forming the basis for ministry to refugees and displaced people from the perspective of God's missio Dei, the church has to complement the teaching of the gospel by embarking on the matters outlined below. In fact the gospel of Christ will not be good news in its fullest sense without social action that meets the needs of the downtrodden.

The church's responsibility towards refugees and the displaced must be informed by the theological framework of God's view for displaced communities as discussed in previous segments above. Care for the refugee is founded on the love for the neighbour and should be exercised despite an environment of scarce resources. As in the words of President Zuma, 'No amount of frustration or anger can ever justify the attacks on foreign nationals and the looting of their shops' (Zuma 2015). Refugees need to be protected from those who take advantage of them due to their vulnerability.

In the light of God's love for the displaced, his people need to encourage others to value the stranger created in God's image, because at some point, some of us did enter a situation of becoming strangers in other countries. That freedom enjoyed in our country is the result of direct or indirect sacrifice of other nations. This is a reality in the SADAC region and other parts of the African continent (Zuma 2015). There is a need to educate the younger generation of these facts in schools, churches and at home. This was one key message God kept reminding Israel of during their stay in Egypt and during their exilic experiences in Babylon and Syria.

God's people are to reach and embrace refugees and displaced people as opposed to unjustified anger towards them. There is a need to preach the message of the love of God and empower both the church and the community on the basis that no one is an island; people live in mutual dependency and coexistence in order to build stronger societies. This fosters the ideal of the rainbow nation and of unity in diversity. Yet if exclusion is tolerated it will produce negative effects and self-destruction, not upon foreigners alone but upon the nation. An example of this is noted in early xenophobic attacks where people from one ethnic group attacked others as outsiders and of a situation where some were attacked or chased away based on their skin pigmentation (Everatt 2010:10). Such criteria also endangered national South Africans that had a dark pigmentation.

It is a reality that to a certain extent civil servants are members of different churches. Pastors and church leaders can play their role by imparting and empowering church members with the Word of God from the perspective of mission Dei to the refugees. The church should have a prophetic voice against matters of social injustices against refugees. It should teach both its members and the community at large how disdaining the abuse of refugees is in God's eyes. Those in the position of authority should exercise power with integrity and create an environment where justice prevails and laws that protect refugees are observed and enforced (cf. Ex 23:9; Dt 1:16). It should teach the message that discourages and denounces dishonesty and bribes in various institutions that provide services to the displaced. It should discourage corrupt officials from taking advantage of vulnerable people by demanding or accepting bribes or creating situations that encourage corruption such as a deliberate slowing down of the process of issuing asylum papers to refugees (Palmary 2002:9).

\section{Recommendations}

Since there has been a continuous trend of brutal attacks on foreigners and refugees, the church has to assume a proactive role where it keeps reminding and teaching its members about the love for the refugee as opposed to only rebuking the acts of violence once they have occurred. Preventive teaching and actions are to be done on a continual basis instead of only focusing on remedial action.

It is recommended that teachings and dialogue at the church level be conducted to help change the wrong perception and attitudes towards refugees. This will help individuals to understand refugees as contributors and not an inconvenience to the society. Sensitisation is also necessary to help the church develop a new perspective of mission where refugees should be viewed as an opportunity to share the Good News to those who would otherwise be deprived from God's will. Refugees may be instrumental in taking the Good News to their communities of origin upon return and replicate the investment given to them during their time of exile.

Lastly, bear in mind that refugee and displacement situations often result from internal conflicts and poor governance from refugee sending nations. It is important that the problem of displacement be addressed from its root cause by engaging churches from refugee sending countries to add their contribution by teaching and denouncing social injustices whenever possible.

\section{Conclusion}

This article shades light on the missio Dei from the perspective of refugees and marginalised individuals. God is depicted as 
being actively involved in his creation. God's mission to the world involves all members of the triune God, each One in a special way: The Father loves the world, the Son accepted to be sent to express the Fathers love to the world and the Holy Spirit empowers the Son and is continuously recreating creation to be in harmony with the Creator. The church has the responsibility to participate in what God is doing in the world. Such participation includes a social responsibility towards the refugees and the destitute of the society to express the love of God to them. Without such obedience, God's missionary plan in the world will be incomplete. As we face the matter of the refugee situation we are to change our perspective from seeking personal benefit and focus more on self-giving acts of the agape love towards those in need.

\section{Acknowledgements Competing interests}

The authors declare that they have no financial or personal relationships which may have inappropriately influenced them in writing this article.

\section{Authors' contributions}

D.S. conducted field research and the writing of the article. S.J. was the project leader and responsible for providing the conceptual basis of missio Dei in the refugee situation. G.L. assisted with the integration of counseling and care-giving concepts and the research tools.

\section{References}

Anderson, R.S., 2010, Christian who counsel: The vocation of holistic therapy, Wipf \& Stock, Oregon.

Auerbach, F., 2001, 'Uprooting racism: Dismantling a system built on a myth', in B. Pityana, F. Auerbach \& B. Manning, Three talks on the topic: 'What is racism?', Centre for the Study of Violence and Reconciliation, viewed 20 July 2016, from http://www.csvr.org.za/docs/racism/whatisracism.pdf

Bevans, S., 2007, 'The church as creation of the Spirit: Unpacking a missionary image', Missiology: An International Review 35(1), 5-21.

Bosch, D.J., 1991, Transforming mission: Paradigm shift in theology of mission, Orbis Books, Maryknoll.

Bromiley, G.W., 1988, 'The international standard Bible encyclopaedia', vol. Q-Z, Eerdmans, Grand Rapids.

Bruce, D., 2002, Police brutality in South Africa, Centre for the study of violence and reconciliation, viewed 19 July 2016, from http://www.csvr.org.za/

Chester, T., 2011, A meal with Jesus: Discovering grace, community, and mission around the table, Crossway, Wheaton.

Cornish, J-J., 2015, South Africa: Xenophobic attacks erupt in South Africa's Limpopo Province, viewed 21 July 2016, from http://allafrica.com/stories/201503051136.htm

Crush, J. \& Pendleton, W., 2004, Regionalizing xenophobia?: Citizen attitudes to immigration and refugee policy in Southern Africa. Southern African Migration Project: Migration Policy Series 20, IDASA \& Queens' University, Cape Town.

Dalton-Greyling, T., 2008, Urban refugees: Definitions, legal position and wellbeing in South Africa, University of Johannesburg, Auckland Park, viewed 28 May 2016, from http://www.tips.org.za/research-archive/annual-forum-papers/item/down oad/1160_8eb3f9ff52be4656304cbee65398b656

Dulles, A.C, 2005, 'The deist minimum', First things, 149, 25-30.

Elliot, J.H., 2011, 'Refugees, resident aliens, and the church as counter-culture', in L. Dykstra \& C. Myers (eds), Liberating biblical study: Scholarship, art and action in

Engelsviken, T., 2003, 'Missio Dei: The understanding and misunderstanding of a theological concept in European churches and missiology', International Review of Mission 92(367), 481-497. (World Council of Churches).

Everatt, D., 2010, 'South African civil society and xenophobia: Strategy \& tactics', The Atlantic Philantropies, viewed 20 July 2016, from http://www.atlanticphilanthropies. $\mathrm{org} /$ research-reports/report-south-african-civil-society-and-xenophobia

Gaebelein, F.E., 1984, Matthew, Mark, Luke, Zondervan, Grand Rapids. (Expositor's Bible commentary, vol. 8)
Gaebelein, F.E., 1990, Genesis-Numbers, Zondervan, Grand Rapids. (Expositor's Bible commentary, vol. 2).

Galgalo, J.D, 2012, African Christianity: The stranger within, Zapf Chancery Publishers Africa, Lumuru.

Gallagher, R.L, 2006, 'The Holy Spirit in the world: In non-Christians, creation and other religions', Asian Journal of Pentecostal Studies 9(1), 17-33.

Goheen, M.W., 2005, 'A critical examination of David Bosch's missional reading of Luke', in C.G. Bartholomew, J.B. Green \& A.C. Thiselton (eds.), Interpretation, reflection, formation, pp. 229-264, Zondervan, Grand Rapids.

Hartenstein, K., 1934, “'Wozu nötigt die Finanzlage der Mission,' Evangelisches Missions-Magazin 79 (1934), 217-229, as quoted by Paul Flett, 'God is missionary God: Missio Dei, Karl Barth, and the Doctrine of the Trinity"', Ph.D. dissertation, Faculty of Theology, Princeton Theological Seminary, Princeton.

Hoffmeyer, J.F, 2001, 'The missional Trinity: Dialog A', Journal of Theology, 40(2), 108.

Holloway, C.W., 2009, 'Adaptation assistance and climate change: Testimony to U.S House of Representatives', Currents in Theology and Mission 37(2), 138-140.

Human Rights Watch, 1998, 'Prohibited persons' abuse of undocumented migrants, asylum-seekers, and refugees in South Africa', Human Rights Watch, viewed 19 July 2016, from York.https://www.hrw.org/legacy/reports98/sareport/

Independent Online, 2013, Police brutality: State acts swiftly, viewed 19 July 2016, from http://www.iol.co.za/news/south-africa/gauteng/police-brutality-state-actsswiftly-1479679

IOL, see Independent Online.

Khan, F., 2007, UNHCR'S local integration: The preferred durable solution annual consultations with NGOs: Lessons learnt and the way forward, University of Cape Town, viewed 20 July 2016, from http://www.refugeerights.uct.ac.za/downloads/ refugeerights.uct.ac.za/local_intergration_sa_context.doc

Ki-moon, B., 2016, 'Refugees and migrants: A crisis of solidarity', SABC News, viewed 7 October 2016, from http://www.sabc.co.za/news/a/d97a98004cb3b4078bc 9dbb995d3d1cd/Refugees-and-Migrants:-A-crisis-of-solidarity-20160905

Landau, L., 2005, Migration, urbanisation and sustainable livelihoods in South Africa: Migration Policy Brief No. 15, Southern Africa Development Project, viewed 20 July 2016, from http://www.queensu.ca/samp/sampresources/samppublications/ policybriefs/brief15.pdf

McDermott, G.R., 2003, 'Which Palestine? Whose land?: A response to Doug Howard', Fides et Historia 15(2), 79-84.

Munroe, M., 2004, Rediscovering the kingdom: Ancient hope for our 21st century world, Destiny Image, Shippensburg.

Mounce, R.H., 1991, Matthew: New international biblical commentary, Hendrickson, Grand Rapids.

Newlands, G., 2006, Christ and human rights: Theology and religion in interdisciplinary perspective series, Ashgate, Burlington.

Nyamnjoh, F.B., 2006, Insiders and outsiders: Citizenship and xenophobia in contemporary Southern Africa, Zed Books, London.

Palmary, I., 2002, Refugees, safety and xenophobia in South African cities: The role of local government: Research report written for the Centre for the Study of Violence and Reconciliation, viewed 20 July 2016, from https://www.researchgate.net/ publication/237288795 Refugees Safety and Xenophobia in South_African Cities The role of local government

Petit, L.P., 2012, 'What would the Egyptian Pharaoh shoshenq I have seen if he had visited the central Jordan valley?', Palestine Exploration Quarterly 144(3), 191-207.

Riggans, W., 1983, Numbers, Westminster Press, Philadelphia.

Scott, J.J., 1995, Jewish background of the New Testament, Baker Books, Grand Rapids.

Sosibo, K., 2013, 'Emidio Macia's death: No way to treat a neighbour', Mail \& Guardian, viewed 20 July 2016, from http://mg.co.za/article/2013-03-15-00emidio-macias-death-no-way-to-treat-a-neighbour

South African History Online, 2015, 'Xenophobic violence in democratic South Africa', South African History Online, viewed 21 July 2016, from http://www.sahistory.org. za/article/xenophobic-violence-democratic-south-africa-timeline\#sthash. ZO2TxwJt.dpuf

Special Assignment, 2014, 'Benoni Dog Unit, South African Broadcasting Corporation', viewed 20 July 2016, from https://www.youtube.com/user/sabcdigitalnews

Stulman, L., 2004, 'Is there life after wreckage?: Jeremiah as a map of hope', Journal for Preachers 27(2), 18-25.

Tromp, B. \& Oatway, J, 2015, 'The brutal death of Emmanuel Sithole', Time Live, viewed 20 July 2016, from http://www.timeslive.co.za/local/2015/04/19/thebrutal-death-of-emmanuel-sithole1

Umezurike, S.A. \& Isike, C., 2013, 'An analysis of the opinions of African immigrants on service delivery by the Department of Home Affairs, South Africa', Inkanyiso Journal of Human \& Social Sciences 5(1), 53-63.

UN, see United Nations.

UNHCR, see United Nations High Commissioner for Refugees.

United Nations High Commissioner for Refugees, 2009, Refugees, asylum seekers, returnees, internally displaced and stateless persons, viewed 30 March 2015, from http://www.unhcr.org/4c11f0be9.pd

United Nations High Commissioner for Refugees, 2013, War's human cost: UNHCR global trends 2013, viewed 30 March 2015, from www.unhcr.org/5399a14f9.html

United Nations High Commissioner for Refugees, 2015, 'Global Trends 2015', viewed 20 July 2016, from http://www.unhcr.org/576408cd7.pdf 
Vorster, J.M., 2007, Christian attitude in the South African liberal democracy, Potchefstroom Theological Publication, Potchefstroom.

Wainwright, G., 1991, 'The doctrine of the Trinity: Where the church stands or fall', Interpretation, 45(2), 117-132., R.B.

Walvoord, J.F. \& Zuck, R.B., 1985, An exposition of the Scriptures by Dallas Seminary Faculty, Victory Books, Auckland. (The Bible knowledge commentary: Old Testament).

Weber, J., 2016, 'God at work along the refugee highway', Christianity Today Magazine, viewed 19 July 2016, from http://www.christianitytoday.org/ministry/mission/

Wicks, J., 2015, KZN xenophobic violence spreads to KwaMashu, viewed 21 July 2015 from http://www.news24.com/SouthAfrica/News/KZN-xenophobic-violencespreads-to-KwaMashu-20150413
Wilkinson, K., 2015, AfricaCheck: Are foreigners 'stealing jobs' in South Africa? Daily Maverick, viewed 20 July 2016, from http://www.dailymaverick.co.za/ article/2015-04-20-africacheck-are-foreigners-stealing-jobs-in-south-africa/\#. V5E83U1-PIU

Wolters, A.M., 2001, Creation regained: Biblical basics for a reformational worldview, Eerdmans, Grand Rapids.

Wright, C.J.H., 2006, The mission of God: Unlocking the Bible's grand narrative, InterVarsity, Downer's Grove.

Zuma, J., 2015, Statement by President Jacob Zuma to the National Assembly on the violence in Kwazulu-Natal directed at foreign nationals, 19 April 2015, viewed 20 July 2016, from http://www.dfa.gov.za/docs/speeches/2015/ zuma0416.htm 